\title{
Arbuscular mycorrhizal fungal diversity in rhizosphere spores versus roots of an endangered endemic tree from Argentina: Is fungal diversity similar among forest disturbance types?
}

\author{
Florencia Soteras ${ }^{\mathrm{a}, *}$, Bruno Coutinho Moreira ${ }^{\mathrm{b}}$, Gabriel Grilli ${ }^{\mathrm{a}}$, Nicolás Pastor ${ }^{\mathrm{a}}$, \\ Flávia Carneiro Mendes ${ }^{\mathrm{b}}$, Daniele Ruela Mendes ${ }^{\mathrm{b}}$, Daniel Renison ${ }^{\mathrm{c}}$, \\ Maria Catarina Megumi Kasuya ${ }^{\mathrm{b}}$, Francisco Adriano de Souza ${ }^{\mathrm{d}}$, Alejandra Becerra ${ }^{\mathrm{a}}$ \\ a Instituto Multidisciplinario de Biología Vegetal-Universidad Nacional de Córdoba-(IMBIV-UNC-CONICET), CC 495, 5000, Córdoba, Argentina \\ ${ }^{\mathrm{b}}$ Departamento de Microbiologia, Universidade Federal de Viçosa, Viçosa, Minas Gerais, Brazil \\ ' Centro de Ecología y Recursos Naturales Renovables “Dr. Ricardo Luti”, Instituto de Investigaciones Biológicas y Tecnológicas, CONICET, Universidad Nacional \\ de Córdoba, Córdoba, Argentina \\ d Embrapa Milho e Sorgo, Núcleo de Biologia Aplicada, Sete Lagoas, Minas Gerais, Brazil
}

\section{A R T I C L E I N F O}

\section{Article history:}

Received 23 January 2015

Received in revised form 31 August 2015

Accepted 9 September 2015

Available online 27 October 2015

\section{Keywords:}

DGGE

Glomeromycota

Symbionts

Soil

Polylepis australis

South America

\begin{abstract}
A B S T R A C T
The aim of this study was to compare the arbuscular mycorrhizal fungal (AMF) community of the rhizosphere and inside the roots of the perennial Polylepis australis tree. Three forest types differing in their structural complexity due to anthropogenic disturbances were chosen at three different sites at the high mountains of central Argentina. Rhizosphere spores and P. australis roots of four randomly selected trees were isolated from 36 soil samples, DNA was extracted and the 18S rDNA fragments were amplified by nested-PCR. The products were analyzed by DGGE and the bands were excised for sequencing. In total, 36 OTUs were defined from 56 DGGE bands successfully sequenced. Forest disturbance types showed similar communities of AMF, as rhizosphere spores and within the roots of $P$. australis. However, DGGE clustering showed mainly differences between rhizosphere spores and root-colonizing AMF. Members of Glomeraceae, Pacisporaceae, Acaulosporaceae and Gigasporaceae were shown in rhizosphere spore samples. Root samples showed only members of Acaulosporaceae and Gigasporaceae, which might be complementary in terms of soil resources exploration. The prevalence of the root system with their community of symbionts might explain the resilience of AMF soil communities to forests structural changes. This study presents evidence of a possible preference in the AMF-P. australis interaction.
\end{abstract}

(c) 2015 Elsevier B.V. All rights reserved.

\section{Introduction}

The high mountain forests of central Argentina are dominated by the perennial tree Polylepis australis Bitt, an endemic species of Argentina (Renison et al., 2013). These mountain forests have been reduced due to the effect of livestock rearing combined with fires, set to promote grass re-growth. The forests remnants are represented by patches differing in their structural complexity and their degree of conservation, depending on their disturbance history. The most preserved forest fragments are located far away from rancher houses, roads and in deep ravines where livestock and fire ignitions are less frequent; while most degraded woodlands are easily accessible (Renison et al., 2011).

\footnotetext{
* Corresponding author.

E-mail address: fsoteras@conicet.gov.ar (F. Soteras).
}

Arbuscular mycorrhizal fungi (AMF) are obligate biotrophic symbionts that colonize $\sim 80 \%$ of the land plant species studied to date. In exchange for plants assimilated carbon, AMF promote hosts nutrition and growth, provide protection against root pathogens and improve soil structure (Smith and Read, 2008). Forest structural changes might affect native AMF communities through changes in vegetation cover, microclimatic conditions or soil physical-chemical characteristics (e.g. Zangaro et al., 2013). However, in previous studies, AMF communities (richness, abundance, diversity and evenness) of $P$. australis mountain forests were not influenced by structural changes (Soteras et al., 2015) nor by increasing livestock density (Menoyo et al., 2009), showing that AMF soil communities might be resilient to these antropogenic disturbances.

The lack of AMF host specificity has been widely acknowledged (Smith and Read, 2008). However, it is becoming evident that exists a degree of selectivity in the plant-AMF association (Davison 
et al., 2011; Helgason et al., 2002; Öpik et al., 2009). Furthermore, in nature a single root system is usually colonized simultaneously by different species of AMF (Saks et al., 2014), and controlled experiments indicated that different AMF species can work synergistically to improve plant growth (Maherali and Klironomos, 2007). There are differences in the AMF colonizing strategies based at the family level, while Gigasporaceae family produce extensive extra-radical mycelia, Glomeraceae mostly colonize inside the roots (De Souza et al., 2005a). Meanwhile, Acaulosporaceae family could be considered as an intermediate strategy, producing low biomass inside and outside the roots (Hart and Reader, 2002; Hart et al., 2001). Moreover, AMF taxa differ in their carbon and phosphorous demand (Pearson and Jakobsen, 1993). Therefore, host-AMF interaction preference could be more related to the reciprocal correspondence of both partners to the same functional group rather than by plant-symbionts identity (Chagnon et al., 2013; Öpik et al., 2009Saks et al., 2014).

The AMF spores of the rhizosphere of $P$. australis at the high mountains forests of central Argentina have been morphologically described (Menoyo et al., 2009; Soteras et al., 2015). However, molecular techniques that could help improving soil community's characterization have not yet been implemented. In addition, research in this high altitudinal forests has been focused on rhizosphere spore communities without considering root-colonizing AMF. The identification of $P$. australis symbionts will allow to state general ecological hypothesis about host-AMF preferences. But, more meaningful due to the endemic nature and current degradation of $P$. australis forests, the identification of rootcolonizing symbionts will increase the knowledge about the most appropriate AMF-inocula to facilitate reforestation efforts. Molecular techniques provide an accurate approach for the identification of the AMF community of the rhizosphere soil and within the target plant roots (Helgason et al., 1998; Husband et al., 2002). The denaturing gradient gel electrophoresis (DGGE) can separate ribosomal DNA (rDNA) fragments of different sequence amplified from total community DNA (Muyzerm and Smalla, 1998). Therefore, this molecular fingerprinting technique together with the sequencing of amplified rDNA fragments has been applied for the AMF community characterization (Kowalchuk et al., 2002; Liang et al., 2008; Öpik et al., 2003).

One of the most important dimensions of AMF niche space is comprised by the root system of host plant species. Other niche axes of these obligate plant symbionts include the soil environment, as AMF allocate great part of their biomass to spores and/or extra-radical mycelia (Bever et al., 2001; Lekberg et al., 2011; Smith and Read, 2008). The resilience of the AMF community against anthropogenic disturbances might be mainly influenced by the degree that below- or aboveground changes physically disrupt the soil (Kladivko, 2001). Disturbance history in the high mountain forests of central Argentina has mainly changed vegetation cover and soil impedance but maintaining the dominant plant species of the community (Renison et al., 2004; 2011). Therefore, symbionts of the root system may have prevailed after disturbance occurrence thus restoring the soil community of the ecosystem. In this context and according to previous field evidence (Menoyo et al., 2009; Soteras et al., 2015), we hypothesized that soils of $P$. australis forests with different disturbance histories are similar in terms of AMF community composition. We expected that the different forest disturbance types (degraded, young and mature) might not strongly affect the AMF community composition thus showing similar DGGE banding patterns. However, considering that coexisting plant species might be colonized by different AMF communities (Vandenkoornhuyse et al., 2003) and that hosts-AMF preference is generally the rule, we hypothesized that $P$. australis is colonized by a subset of the soil AMF. We expected that this perennial host would show a tight relationship with AMF taxa belonging to the same functional group (i.e. AMF members of the Gigasporaceae family).

To test these predictions, the aim of this study was to compare the AMF community of the rhizosphere spores of $P$. australis trees with the root-colonizing AMF community in three forests types differing in their structural complexity, using nested-PCR DGGE analysis of the 18S rDNA followed by sequencing of excised bands.

\section{Materials and methods}

\subsection{Field sampling of rhizosphere soil and root system}

During June 2012 soil samples were collected from three $P$. australis forest disturbance types (degraded forest, young forest and mature forest) at three river basins (spatial replicates) of the high mountains of central Argentina. Lateral roots and rhizospheric soil were collected with a trowel $15 \mathrm{~cm}$ away from the main trunk and below the soil litter layer $(0-20 \mathrm{~cm}$ depth) of four randomly selected $P$. australis trees separated for at least $20 \mathrm{~m}$ of distance. Thus rhizosphere soil samples totalized 36 replicates ( 4 trees $\times 3$ forest types $\times 3$ sites).

Forest disturbance types have been shaped by livestock and fire management and differed among each other according to their structural complexity (e.g. canopy cover, age and height of the oldest tree, exposed rock surfaces; Renison et al., 2011). Mean temperature for the coldest and warmest months are $5^{\circ} \mathrm{C}$ and $11.4^{\circ} \mathrm{C}$, respectively, with no frost-free period. Mean annual precipitation is $840 \mathrm{~mm}$, being concentrated in the warmest months (October-April) (Cabido et al., 1987).

\subsection{Spore isolation from soil and DNA extraction}

AMF spores were extracted by wet sieving and decanting of $25 \mathrm{~cm}^{3}$ of soil, followed by centrifugation in sucrose solution (50\% $\mathrm{w} / \mathrm{v})$ (Walker et al., 1982). The material on the top sieve $(500 \mu \mathrm{m})$ was discarded and the content on the fine sieve $(38 \mu \mathrm{m})$ was suspended in water and centrifuged for $4 \mathrm{~min}$ at $3000 \mathrm{rpm}$. The resulting pellet was resuspended and centrifuged in sucrose for $2 \mathrm{~min}$ at $2000 \mathrm{rpm}$. Finally, the suspension was transferred to a $20 \mathrm{ml}$ tube and stored at $4{ }^{\circ} \mathrm{C}$ until DNA extraction.

DNA extraction from the isolated spores was performed using UltraClean $^{\mathrm{TM}}$ soil DNA kit (MO BIO Laboratories, Solana beach, CA, USA) following the manufacturer's specifications. DNA extracted was checked by agarose gel electrophoresis $(0.8 \%)$, stained with ethidium bromide and visualized under UV light.

\subsection{DNA extraction from root system}

Roots were carefully separated from rhizosphere samples and washed with tap water. Then the samples were dried for $48 \mathrm{~h}$ at $50{ }^{\circ} \mathrm{C}$ and stored at $-5{ }^{\circ} \mathrm{C}$ until DNA extraction. Root material $(60 \mathrm{mg})$ was ground in a mortar with liquid nitrogen and DNA extraction was performed following manufacturer's protocol of the Invisorb ${ }^{\mathbb{R}}$ Spin Plant Mini Kit (Invitek, Berlin, Germany).

\subsection{Amplification of $18 \mathrm{~S}$ rDNA fragments by nested-PCR}

In order to characterize the AMF community of soil and roots the methodology proposed by Liang et al. (2008) with modifications was followed. Nested-PCR reactions were done in a sterile microcentrifuge $0.5 \mathrm{ml}$ tube using GoTaq ${ }^{\circledR}$ Flex DNA Polymerase (Promega, Madison, USA) according to manufacturer's advices, adding elution buffer ( $20 \mathrm{mM}$ Tris- $\mathrm{HCl}, 50 \mathrm{mM} \mathrm{KCl}, \mathrm{pH} 8.4)$ and reaching a total reaction volume of $50 \mu \mathrm{l}$.

A 580 bp sequence of the SSU rRNA gene was amplified using the universal eukaryotic primer NS31 (Simon et al., 1992) and the 
AM1 fungal-specific primer (Helgason et al., 1998). The reaction mixture for performing the PCR was composed of $200 \mu \mathrm{M}$ each of the four deoxynucleoside triphosphates, $1.5 \mathrm{mM} \mathrm{MgCl}_{2}, 0.2 \mu \mathrm{M}$ of each primer and $1.25 \mathrm{U}$ GoTaq DNA polymerase Flex ${ }^{\mathbb{R}}$. An aliquot $\left(0.8 \mu \mathrm{g} \mu \mathrm{l}^{-1}\right)$ of BSA (Promega) was also added. Also $5 \mu \mathrm{l}$ of DNA spores and roots were added. The cycling was made on a Mastercycler Ep Gradient (Eppendorf) thermal cycler. The regime used was as follows: first cycle at $94^{\circ} \mathrm{C}$ for $1 \mathrm{~min}$, then $1 \mathrm{~min}$ at $66^{\circ} \mathrm{C}$ and $1.30 \mathrm{~min}$ at $72^{\circ} \mathrm{C}$, followed by 30 cycles of $94^{\circ} \mathrm{C}(30 \mathrm{~s})$, $66^{\circ} \mathrm{C}(1 \mathrm{~min})$ and $72{ }^{\circ} \mathrm{C}(1.30 \mathrm{~s})$, and a final elongation at $72^{\circ} \mathrm{C}$ for $10 \mathrm{~min}$. To confirm the PCR amplification and quality, the products were checked by agarose gel electrophoresis $(0.8 \%)$, stained with ethidium bromide and visualized under UV light.

The PCR products were diluted ten times with MilliQ sterile water, then $1 \mu \mathrm{l}$ of the diluted amplicons were used as a template for a second PCR, using the primers NS31-GC (Kowalchuk et al., 2002) and Glo1 (Cornejo et al., 2004) with the same reaction mixture detailed formerly. Conditions for the nested-PCR were: an initial denaturalization step at $94^{\circ} \mathrm{C}$ ( $5 \mathrm{~min}$ ), followed by 35 cycles of a denaturalization at $94{ }^{\circ} \mathrm{C}(45 \mathrm{~s})$, then $52^{\circ} \mathrm{C}(45 \mathrm{~s})$ and $72{ }^{\circ} \mathrm{C}$ ( $1 \mathrm{~min}$ ), and a final elongation at $72^{\circ} \mathrm{C}$ for $30 \mathrm{~min}$. To confirm the PCR amplification and quality, the products were checked by agarose gel electrophoresis (1.5\%), stained with ethidium bromide and visualized under UV light. PCR products were stored at $-20^{\circ} \mathrm{C}$ until the denaturing gradient gel electrophoresis (DGGE) analyses (Liang et al., 2008).

\subsection{Nested-PCR products analysis by DGGE}

In order to compare DGGE bands, Glomeromycota reference markers were performed using $15 \mu \mathrm{l}$ of a mixture of Glomus clarum from in vitro collection (Laboratory of Mycorrhizal Associations, Universidade Federal de Viçosa-Viçosa, Brazil), Acaulospora koskei SCT406A, A. tuberculata SCT250B, Gigaspora albida PRN201A, Gi. decipiens SCT304A and Scutellospora heterogama PNB102A, collections from the International Glomeromycota Culture of the Regional University of Blumenau (FURB), Santa Catarina.

A sample of $10 \mu \mathrm{l}$ of the products of the nested-PCR was analyzed by DGGE (Dcode ${ }^{\mathrm{TM}}$ System-BIO Rad California, USA). Electrophoresis vertical gels contained polyacrylamide (37.5:1 acrylamide:bisacrylamide), $8 \%$ (wt/v) of Tris-acetate-EDTA (TAE) buffer $1 \mathrm{X}$ (Tris/acetic acid/EDTA, pH 8.0). A final gradient varying from $35 \%$ at the top to $55 \%$ at the bottom of the gel was prepared aided by the Gradient Hoefer SG50 (Amersham Biosciences). The condition of $100 \%$ denaturant was formed by $7 \mathrm{M}$ urea (Sigma, Cat\#U5378) plus 40\% v/v formamide (Sigma, Cat\#F9037). DGGE was performed in TAE $1 \mathrm{X}$ buffer at a constant temperature of $60^{\circ} \mathrm{C}$ at $80 \mathrm{~V}(10 \mathrm{~min})$, followed by $60 \mathrm{~V}(20 \mathrm{~h})$. DGGE gels were stained with 1X SYBR GOLD ${ }^{\mathbb{R}}$ (Sigma-Aldrich) according to manufacturer's advices. Gels were visualized under UV light, captured and digitized using a photodocumentation imaging system (Loccus Biotecnologic L-Pix Chemi). Dendrograms were constructed with the Bionumeric software version 6.0 (Applied Maths, Inc., Austin, Texas, USA) using Jaccard's similarity index and cluster analysis with the un-weighted pair-group method with arithmetic averages (UPGMA).

\subsection{Nested-PCR products sequencing and OTUs delimitation}

From the DGGE gels, more frequent and intense bands were excised and transferred to microtubes of $0.5 \mathrm{ml}$ containing $30 \mu \mathrm{l}$ of MilliQ sterile water for re-amplification by PCR.

The new PCR reaction was performed as the nested-PCR described formerly, using NS31 and Glo1 primers but without GCclamp. The DNA fragments were sequenced using primer Glo1 and NS31 by the Macrogen Company (Macrogen Inc., Korea). The sequences obtained were analyzed using SEQUENCHER software version 4.1.4 (Gene Codes Corporation, Ann Arbor, Michigan, USA).

Sequences were grouped into operational taxonomic units (OTUs) with the following criteria: $\geq 97 \%$ of identity and no more than $10 \mathrm{bp}$ shorter than the query length. Sequence of each OTU were compared with those in the MaarjAM database (Öpik et al., 2010) and in the National Center for Biotechnology Information (NCBI) by conducting a BLAST-n (Altschul et al., 1997) and morphospecies taxa were assigned following the criteria previously stated. Sequences not similar to known taxa were automatically aligned using the MAFT web service in Jalview version 2.8 (Waterhouse et al., 2009) together with all virtual taxa type sequences of MaarjAM database (status 31.03.2013) and the closest sequences. Neighbor-joining analysis (F84 model with gamma substitution rates and bootstrapping over 100 runs) was performed in TOPALi v2.5 (Milne et al., 2004). New OTUs were defined based on bootstrap support and the same criteria formerly described. Sequences of all the determined OTUs were submitted to the European Nucleotide Archive of EMBL-EBI (accession numbers from LM993888-LM993943).

Following the removal of sequences of Glomeromycota families that did not appear in the sample and potential sequencing artifacts, a Bayesian tree was built using MrBayes version 3.1.2 software (Ronquist and Huelsenbeck, 2003) including the 36 OTUs defined and the closest GenBank sequences. The best nucleotide substitution model (GTR with gamma distributed rate heterogeneity among sites) according to the Akaike Information Criterion (AIC) was determined with jModelTest version 2.1.4 (Darriba et al., 2012).

\section{Results}

\subsection{Nested-PCR products analysis by DGGE}

The DGGE analysis of the nested-PCR products evidenced a total of 56 bands that were used for pattern comparison based on band matching and intensity. DGGE clustering showed that AMF community was mainly different between rhizosphere spores and roots (bootstrap 90\%) rather than among forest structural types, excepting for three DGGE bands of spore samples (6-8) that were grouped with root bands (Fig. S1).

\subsection{DGGE excised bands sequencing}

In total 56 bands grouped in 36 OTUs that belonged to four AMF families (Glomeraceae, Acaulosporaceae, Gigasporaceae and Pacisporaceae) were successfully sequenced. Among them, 18 bands could be assigned to known AMF morphospecies.

Forest structural types shared most of the OTUs present in the rhizosphere of $P$. australis. Spore bands revealed that OTU4 (accession number: LM993898, best score: 100\% of query coverage and 99\% of identity) and OTU5 (accession number: LM993908, best score: $98 \%$ of query coverage and $98 \%$ of identity) in the rhizosphere of the degraded and mature forests matched with Acaulospora laevis. This morphospecie was also found in the young forests rhizosphere. The OTU7 appeared in the rhizosphere of mature forest type and its closest match was with Gigaspora margarita (accession number: LM993919, 100\% of query coverage and $98 \%$ of identity). Root bands showed OTU1 which was closely related with $\mathrm{Gi}$. rosea (accession number: LM993918, best score: $98 \%$ of query coverage and $98 \%$ of identity) as the only known morphospecies in both degraded and mature forests (Table S1).

The sequences of excised bands showed differences between the AMF community of spores and roots. DGGE bands of spore samples (46 successfully sequenced) revealed 31 OTUs belonging 


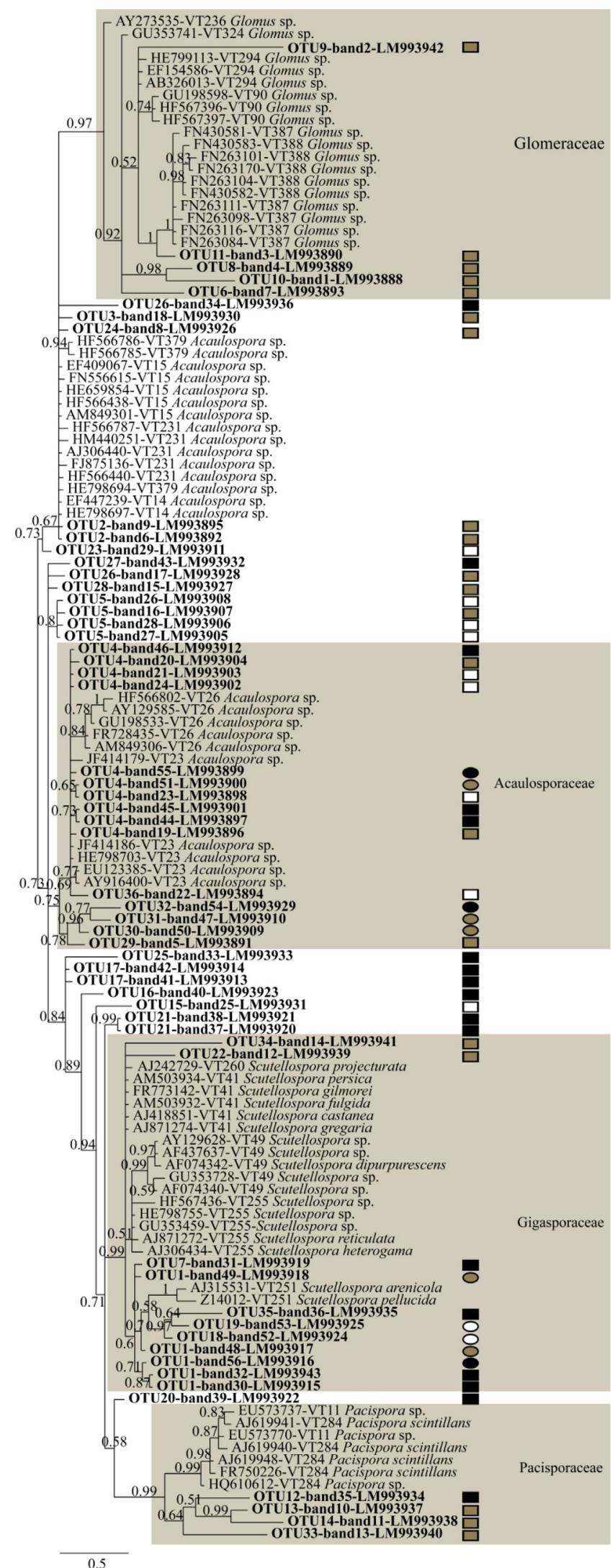

Fig. 1. Phylogram of the midpoint-rooted majority rule consensus tree based on Bayesian analysis of the nested-PCR DGGE bands sequences of spores and roots of $P$. australis rhizosphere in three forest types. Posterior probabilities $>0.5$ are shown. OTUs determined in this study are highlighted in bold along with DGGE band number as designated in Fig. S1 and ENA accession number. Symbols at the right of the tree indicate OTUs detected from spores of the rhizosphere (squares) and OTUs to the four families. Contrary to that, DGGE bands of root samples showed only affiliations with Acaulosporaceae and Gigasporaceae (7 OTUs). From the total of OTUs inside $P$. australis roots only 2 were also present as spores: OTU1 and OTU4, respectively related to $G i$. rosea and Acaulospora laevis. Gigasporaceae OTU18, OTU19 and OTU35 were related to Scutellospora arenicola,Scutellospora pellucida, Gi. roseae (OTU1) and Gi. margarita (OTU7) (Fig. 1). Pacispora OTU12, OTU13, OTU14 and OTU33 were related to Pacispora scintillans (Fig. 1).

\section{Discussion}

In accordance with the hypothesis stated and as with Soteras et al. (2015), forest disturbance types did not influence the AMF community, as molecularly characterized. Rather, differences in the composition between rhizosphere spores and root-colonizing AMF of $P$. australis were observed, the latter showing the lower diversity. The different forest disturbance types of $P$. australis have been shaped by the disturbance history of the high mountain ecosystems of central Argentina. Livestock rearing and intentional fires to promote grass re-growth are the main anthropogenic impacts on these forests, causing changes in forest structural complexity, mainly cover reduction and soil compactation increase (Renison et al., 2004; 2011). However, dominant tree and shrub species are still present in the different forest types thus maintaining the root system with their community of symbionts. The prevalence of the root ecosystem is probably the cause of the lack of differences among forest disturbance types of the AMF community, characterized by either morphological or molecular techniques.

Similar to previous morphological approaches of rhizosphere samples of $P$. australis (Soteras et al., 2015), excised bands sequences were related to Gi. rosea OTU1 (accession number: LM993918) and Gi. margarita OTU7 (accession number: LM993919) according to the BLAST against MaarjAM database. Of the total OTUs defined, OTU4 (accession number: LM993898), affiliated to Acaulospora laevis, was the most frequent (18\% of the sequenced bands). This morphospecies was also morphologically recorded by Menoyo et al. (2009) at the high mountain forests of central Argentina. In addition, members of Pacispora sp., previously identified by morphological techniques were detected in this study, thus confirming its presence and increasing the current knowledge about the distribution range of this genus (Novas et al., 2005).

As was revealed by other authors (Öpik et al., 2009Saks et al., 2014; Torrecillas et al., 2011), and supporting the hypothesis stated, $P$. australis trees were colonized by a subset of the rhizosphere spore AMF taxa. Among the four different Glomeromycota families obtained from DGGE bands of the spores samples, only members of Acaulosporaceae and Gigasporaceae were found inside $P$. australis roots. There are numerous potential hypotheses that could explain the differences among AMF root-colonizing and spore community.

First, there could be a degree of host specificity or preference by the AMF community of the rhizosphere, or vice versa (Chagnon et al., 2013; Davison et al., 2011; Helgason et al., 2002; Öpik et al., 2009Torrecillas et al., 2011). As was depicted by Öpik et al. (2009) and Davison et al. (2011) for specialist vs. generalist forest species and by Torrecillas et al. (2011) for annual vs. perennial hosts, the preference of the $P$. australis-AMF association may be occurring at the level of functional groups. The "competitive" members of Gigasporaceae (Chagnon et al., 2013), shown inside the roots of the target tree as expected, tend to demand high carbon supply from

detected inside $P$. australis roots (circles). Color coding: gray, degraded forest; white, young forest and black, mature forest. 
plants, producing extensive extra-radical mycelia (Hart and Reader, 2002; Pearson and Jakobsen, 1993) and large spores (De Souza et al., 2005a,b). Therefore, in general this Glomeromycota family colonizes perennial species, while members of the ruderal family Glomeraceae typically colonize roots of herbaceous annual plants (Chagnon et al., 2013; Grilli et al., 2015).

Additionally, OTUs related to Acaulosporaceae family were found colonizing P. australis roots. Acaulospora spp. have been previously recorded colonizing roots of mountain grassland species of central Argentina (Öpik et al., 2013) and they are widespread in forest ecosystems in Brazil (Zangaro et al., 2013). In the North Yorkshire, OTUs related to Acaulosporaceae were also found as the most frequent in root of Hyacinthoides non-scripta (Helgason et al., 1999). This family was not expected to colonize $P$. australis roots. However, due to the low production of both extraand intra-radical hyphae and it low competition for spatial niche, taxa belonging to this "stress tolerant" family may colonize together with Glomeraceae or Gigasporaceae (Chagnon et al., 2013; Maherali and Klironomos, 2007).

Second, dormant spores may be present in the AMF rhizosphere pool and could potentially initiate root colonization of host plants under certain conditions or during one season (Hart et al., 2001). Hempel et al. (2007) evidenced different AMF taxa as intra- or extra-radical mycelium or as spores in a grassland ecosystem. In agreement with these and other author findings (Saks et al., 2014; Torrecillas et al., 2011), some of the OTUs found in root samples (Acaulospora OTU30, OTU31 and OTU32; Gigasporaceae OTU18 and OTU19) were not found as spores. Probably, these taxa were not present as this propagule type at the sampling time (Saks et al., 2014; Torrecillas et al., 2011). Further seasonal sampling may reveal other AMF taxa inside tree roots.

Third, AMF root-colonizing taxa could vary along the target plant life cycle (Kuramae et al., 2013). For instance, Husband et al. (2002) showed that the richness and diversity of AMF community colonizing Tetragastris panamensis roots decreased with seedlings age. This issue should be tested in future studies.

Although general patterns of the rhizosphere AMF community could be evidenced using DGGE analyses, a possible limitation of this molecular technique is that rare AMF taxa may not be detected. Future root analysis performing clones from the Sanger sequencing products (Kowalchuk et al., 2002; Öpik et al., 2003) or directly pyrosequencing of the samples could help revealing them (Öpik et al., 2009).

Finally, it should be kept in mind that members of Archaeosporaceae and Paraglomeraceae cannot be detected using the NS31/AM1 primer combination applied in this work (Helgason et al., 1998). However, AMF taxa belonging to these families were not previously detected in morphological approaches of the spores of $P$. australis rhizosphere (Menoyo et al., 2009; Soteras et al., 2015).

This study presents evidence of a possible preference in the AMF-P. australis interaction. Only Gigasporaceae and Acaulosporaceae members, which may be functionally complementing, were inside the roots of this perennial woody host. As was widely evidenced, different AMF assemblages had distinctive effects on plant performance (Bever et al., 2001); thus our findings could be of great relevance for the reforestation activities with $P$. australis, as AMF communities could be isolated and used for inoculation of nursery trees. During field transplant, seedlings have to face with livestock browsing; therefore higher biomass production through the inoculation with the symbionts that show a degree of specificity, which are likely the most beneficial, might improve reforestation success. We suggest future researches should attain the hypothesis of the specificity of the interaction between hosts and AMF belonging to the same functional group, including plants of the high mountain of central Argentina of different life-history strategies.

\section{Acknowledgements}

This work was financially supported by Agencia de Promoción Científica y Tecnológica - PICT 438-2006, Consejo Nacional de Investigaciones Científicas y Técnicas -PIP 0269, Ministerio de Educación de la Nación (Secretaría de Políticas Universitarias-Res. 474), Secretaría de Ciencia y Técnica de la Universidad Nacional de Córdoba, Argentina and Idea Wild Foundation. F.S. and N.P are grateful to CONICET for providing their fellowships. A.B., D.R., and G.G. are researchers of CONICET. The authors gratefully acknowledge to Marro N. for helping with samples processing.

\section{Appendix A. Supplementary data}

Supplementary data associated with this article can be found, in the online version, at http://dx.doi.org/10.1016/j. apsoil.2015.09.003.

\section{References}

Altschul, S.F., Madden, T.L., Schaffer, A.A., Zhang, Z., Miller, W., Lipman, D.J., 1997. Gapped BLAST and PSI-BLAST: a new generation of protein database search programs. Nucl. Acids Res. 25, 3389-3402.

Bever, J.D., Schultz, P.A., Pringle, A., Morton, J.B., 2001. Arbuscular mycorrhizal fungi: more diverse than meets the eye, and the ecological tale of why. Bioscience 51 923-932.

Cabido, M., Breimer, R., Vega, G., 1987. Plant communities and associated soil types in a high plateau of the Cordoba Mountains, Central Argentina. Mt. Res. Dev. 7, 25-42.

Cornejo, P., Azcón-Aguilar, C., Miguel Barea, J., Ferrol, N., 2004. Temporal temperature gradient gel electrophoresis (TTGE) as a tool for the characterization of arbuscular mycorrhizal fungi. FEMS Microbiol. Lett. 241 265-270.

Chagnon, P.L., Bradley, R.L., Maherali, H., Klironomos, J.N., 2013. A trait-based framework to understand life history of mycorrhizal fungi. Trends Plant. Sci. 18 484-491.

Darriba, D., Taboada, G.L., Doallo, R., Posada, D., 2012. jModelTest 2: more models, new heuristic and parallel computing. Nat. Methods 9, 772.

Davison, J., Öpik, M., Daniell, T.J., Moora, M., Zobel, M., 2011. Arbuscular mycorrhizal fungal communities in plant roots are not random assemblages. FEMS Microbiol. Ecol. 78, 103-115.

De Souza, F.A., Dalpé, Y., Declerck, S., de la Providencia, I., Séjalon-Delmas, N., 2005a. Life history strategies in Gigasporaceae: insight from monoxenic culture. In: Declerck, S., Fortin, J.A., Strullu, D.-G. (Eds.), In Vitro Culture of Mycorrhizas. Springer Berlin, Heidelberg, pp. 73-91.

De Souza, F.A., Declerck, S., Smit, E., Kowalchuk, G.A., 2005b. Morphological, ontogenetic and molecular characterization of Scutellospora reticulata (Glomeromycota). Mycol. Res. 109, 697-706.

Grilli, G., Urcelay, C., Galetto, L., Davison, J., Vasar, M., Saks, Ü., Jairus, T., Öpik, M. 2015. The composition of arbuscular mycorrhizal fungal communities in the roots of a ruderal forb is not related to the forest fragmentation process. Environ. Microbiol. 17, 2709-2720. doi:http://dx.doi.org/10.1111/1462 2920.12623.

Hart, M.M., Reader, R.J., 2002. Taxonomix basis for variation in the colonization strategy of arbuscular mycorrhizal fungi. New Phytol. 153, 335-344.

Hart, M.M., Reader, R.J., Klironomos, J.N., 2001. Life-history strategies of arbuscular mycorrhizal fungi in relation to their successional dynamics. Mycologia 93, $1186-1194$.

Helgason, T., Daniell, T.J., Husband, R., Fitter, A.H., Young, J.P.W., 1998. Ploughing up the wood wide web? Nature 394, 431.

Helgason, T., Fitter, A.H., Young, J.P.W., 1999. Molecular diversity of arbuscular mycorrhizal fungi colonising Hyacinthoides non-scripta (bluebell) in a seminatural woodland. Mol. Ecol. 8, 659-666.

Helgason, T., Merryweather, J., Denison, J., Wilson, P., Young, J.P.W., Fitter, A.H., 2002 Selectivity and functional diversity in arbuscular mycorrhizas of co-occurring fungi and plants from a temperate deciduous woodland. J. Ecol. 90, 371-384.

Hempel, S., Renker, C., Buscot, F., 2007. Differences in the species composition of arbuscular mycorrhizal fungi in spore, root and soil communities in a grassland ecosystem. Environ. Microbiol. 9, 1930-1938.

Husband, R., Herre, E.A., Young, J.P.W., 2002. Temporal variation in the arbuscular mycorrhizal communities colonising seedlings in a tropical forest. FEMS Microbiol. Ecol. 42, 131-136.

Kladivko, E.J., 2001. Tillage systems and soil ecology. Soil Till. Res. 61, 61-76.

Kowalchuk, G.A., de Souza, F.A., Van Veen, J.A., 2002. Community analysis of arbuscular mycorrhizal fungi associated with Ammophila arenaria in Dutch coastal sand dunes. Mol. Ecol. 11, 571-581.

Kuramae, E.W., Verbruggen, E., Hillekens, R., Hollander, M., Röling, W.F.M., van der Heijden, M.G.A., Kowalchuk, G.A., 2013. Tracking fungal community responses to maize plants by DNA- and RNA-based pyrosequencing. PLoS One 8 , e69973. 
Lekberg, Y., Meadow, J., Rohr, J.R., Redecker, D., Zabinksli, C.A., 2011. Importance of dispersal and thermal envrionment for mycorrhizal communities: lessons from Yellowstone National Park. Ecology 82, 1292-1302.

Liang, Z., Drijber, R., Lee, D., Dwiekat, I., Harris, S., Wedin, D., 2008. A DGGE-cloning method to characterize arbuscular mycorrhizal community structure in soil. Soil. Biol. Biochem. 40, 956-966.

Maherali, H., Klironomos, J.N., 2007. Influence of phylogeny on fungal community assembly and ecosystem functioning. Science 316, 1746-1748.

Menoyo, E., Renison, D., Becerra, A.G., 2009. Arbuscular mycorrhizas and performance of Polylepis australis trees in relation to livestock density. For. Ecol. Manag. 258, 2676-2682.

Milne, I., Wright, F., Rowe, G., Marshal, D.F., Husmeier, D., McGuire, G., 2004. TOPALi: software for automatic identification of recombinant sequences within DNA multiple alignments. Bioinformatics 20, 1806-1807.

Muyzerm, G., Smalla, K., 1998. Application of denaturing gradient gel electrophoresis (DGGE) and temperature gradient gel electrophoresis (TGGE) in microbial ecology. Antonie van Leeuwenhoek 73, 127-141.

Novas, M.V., Fracchia, S., Menéndez, A., Cabral, D., Godeas, A., 2005. Glomus patagonicum sp. nov. (Glomerales), a new arbuscular mychorrhizal fungus from Argentina. Nova Hedwigia 80, 533-540.

Öpik, M., Moora, M., Liira, J., Kõljalg, U., Zobel, M., Sen, R., 2003. Divergent arbuscular mycorrhizal fungal communities colonize roots of Pulsatilla spp. in boreal Scots pine forest and grassland soils. New Phytol. 160, 581-593.

Öpik, M., Metsis, M., Daniell, T.J., Zobel, M., Moora, M., 2009. Large-scale parallel 454 sequencing reveals host ecological group specificity of arbuscular mycorrhizal fungi in a boreonemoral forest. New Phytol. 184, 424-437.

Öpik, M., Vanatoa, A., Vanatoa, E., Moora, M., Davison, J., Kalwij, J.M., Reier, U., Zobel, M., 2010. The online database MaarjAM reveals global and ecosystemic distribution patterns in arbuscular mycorrhizal fungi (Glomeromycota). New Phytol. 188, 223-241.

Öpik, M., Zobel, M., Cantero, J.J., Davison, J., Facelli, J.M., Hiiesalu, I., Jairus, T., Kalwij, J.M., Koorem, K., Leal, M.E., Liira, J., Metsis, M., Neshataeva, V., Paal, J., Phosri, C. Põlme, S., Reier, Ü., Saks, Ü., Schimann, H., Thiéry, O., Vasar, M., Moora, M., 2013. Global sampling of plant roots expands the described molecular diversity of arbuscular mycorrhizal fungi. Mycorrhiza 23, 411-430.

Pearson, J.N., Jakobsen, I., 1993. Symbiotic exchange of carbon and phosphorus between cucumber and three arbuscular mycorrhizal fungi. New Phytol. 124 481-488.
Renison, D., Hensen, I., Cingolani, A.M., 2004. Anthropogenic soil degradation affects seed viability in Polylepis australis mountain forests of central Argentina. For. Ecol. Manag. 196, 327-333.

Renison, D., Hensen, I., Suarez, R., 2011. Landscape structural complexity of highmountain Polylepis australis forests: a new aspect of restoration Goals. Rest. Ecol. 19, 390-398.

Renison, D., Cuyckens, G.A.E., Pacheco, S., Guzmán, G.F., Grau, H.R., Marcora, P., Robledo, G.L., Cingolani, A.M., Dominguez, J., Landi, M., Bellis, L., Hensen, I., 2013. Distribucián y estado de conservacián de las poblaciones de órboles y arbustos del género Polylepis (Rosaceae) en las montañas de Argentina. Ecol. Austral 23, 27-36.

Ronquist, F., Huelsenbeck, J.P., 2003. MrBayes 3: Bayesian phylogenetic inference under mixed models. Bioinformatics 19, 1572-1574.

Saks, Ü., Davison, J., Öpik, M., Vasar, M., Moora, M., Zobel, M., 2014. Root-colonizing and soil-borne communities of arbuscular mycorrhizal fungi in a temperate forest understorey. Botany 92, 277-285.

Simon, L., Lalonde, M., Bruns, T.D., 1992. Specific amplification of 18 S fungal ribosomal genes from vesicular-arbuscular endomycorrhizal fungi colonizizing roots. App. Environ. Microbiol. 58, 291-295.

Smith, S.E., Read, D., 2008. Mycorrhizal Symbiosis. Academic Press, Great Britain pp. 815.

Soteras, F., Grilli, G., Cofré, N., Marro, N., Becerra, A., 2015. Arbuscular mycorrhizal fungal composition in high montane forests with different disturbance histories in central Argentina. App. Soil. Ecol. 85, 30-37.

Torrecillas, E., Alguacil, M., Roldán, A., 2011. Differences in the AMF diversity in soil and roots between two annual and perennial gramineous plants co-occurring in a Mediterranean, semiarid degraded area. Plant Soil 354, 97-106.

Vandenkoornhuyse, P., Ridgway, K.P., Watson, I.J., Fitter, A.H., Young, J.P.W., 2003. Co-existing grass species have distinctive arbuscular mycorrhizal communities. Mol. Ecol. 12, 3085-3095.

Walker, C., Mize, W., McNabb, H.S., 1982. Populations of endogonaceous fungi at two populations in central Iowa. Can. J. Bot. 60, 2518-2529.

Waterhouse, A.M., Procter, J.B., Martin, D.M.A., Clamp, M., Barto, G.J., 2009. Jalview Version 2-a multiple alingnment editor and analysis workbench. Bioinformatics 25, 1189-1191.

Zangaro, W., Rostirola, L.V., de Souza, P.B., de Almeida Alves, R., Lescano, L.E., Rondina, A.B., Nogueira, M.A., Carrenho, R., 2013. Root colonization and spore abundance of arbuscular mycorrhizal fungi in distinct successional stages from an Atlantic rainforest biome in southern Brazil. Mycorrhiza 23, 221-233. 